\title{
ON THE LONG-TERM MACROECONOMIC EFFECTS OF SOCIAL SPENDING IN THE UNITED STATES (*)
}

\author{
Alfredo Marvão Pereira \\ The College of William and Mary
}

Jorge M. Andraz

Faculdade de Economia, Universidade do Algarve, CEFAGE (UALG) - Center for Advanced Studies in Management and Economics

\author{
College of William and Mary \\ Department of Economics \\ Working Paper Number 151
}

This Version: April 2014

$\left(^{*}\right)$ We would like to thank Rui Pereira for very helpful comments and suggestions. 
COLLEGE OF WILLIAM AND MARY

DEPARTMENT OF ECONOMICS

WORKING PAPER \# 151

April 2014

\title{
ON THE LONG-TERM MACROECONOMIC EFFECTS OF SOCIAL SPENDING IN THE UNITED STATES
}

\begin{abstract}
We estimate the long-term impact of changes in social security and social protection spending on economic performance in the USA. We estimate a VAR model relating GDP, unemployment rates, saving rates, and social spending. Our results suggest that social spending has significant distortionary effects in the labor markets as measured by its long term effects on the unemployment rate, which translate into a detrimental effect on long-term output, this despite a positive, albeit small, effect on the gross savings rate. There are important policy implications of these results. If one considers the systems as they are, any further expansion in their generosity would have detrimental long-term effects. These detrimental effects, however, are neither an indictment of social spending or evidence against extension of benefits. What they highlight is the need to carefully consider the financing mechanisms currently used and the need to align benefits and contributions in the pension component of social security and the need to find a taxrevenue mix that is less distortionary for the unfunded benefits.
\end{abstract}

JEL Classification: C32, H55.

Key words: Social spending, unemployment, saving, output.

\author{
Alfredo Marvão Pereira \\ Department of Economics, \\ The College of William and Mary, Williamsburg, USA \\ PO Box 8795, Williamsburg, VA 23187 \\ ampere@,wm.edu
}

Jorge M. Andraz

Faculdade de Economia, Universidade do Algarve, CEFAGE (UALG) - Center for Advanced Studies in Management and Economics Campus de Gambelas, 8000-139 Faro, Portugal.

jandraz@ualg.pt 


\title{
ON THE LONG-TERM MACROECONOMIC EFFECTS OF SOCIAL SPENDING IN THE UNITED STATES (*)
}

\author{
Alfredo M. Pereira \\ Department of Economics, \\ College of William and Mary, Williamsburg, VA 23187 \\ Email: ampere@wm.edu \\ Jorge M. Andraz \\ Faculdade de Economia, Universidade do Algarve, \\ CEFAGE (UALG) - Center for Advanced Studies in Management and Economics, \\ Campus de Gambelas, 8000-139 Faro, Portugal. \\ Email: jandraz@ualg.pt
}

\begin{abstract}
We estimate the long-term impact of changes in social security and social protection spending on economic performance in the USA. We estimate a VAR model relating GDP, unemployment rates, saving rates, and social spending. Our results suggest that social spending has significant distortionary effects in the labor markets as measured by its long term effects on the unemployment rate, which translate into a detrimental effect on long-term output, this despite a positive, albeit small, effect on the gross savings rate. There are important policy implications of these results. If one considers the systems as they are, any further expansion in their generosity would have detrimental long-term effects. These detrimental effects, however, are neither an indictment of social spending or evidence against extension of benefits. What they highlight is the need to carefully consider the financing mechanisms currently used and the need to align benefits and contributions in the pension component of social security and the need to find a taxrevenue mix that is less distortionary for the unfunded benefits.
\end{abstract}

JEL Classification: C32, H55.

Key words: Social spending, unemployment, saving, output.

\section{Introduction}

The objective of this paper is to determine the magnitude of the macroeconomic distortions induced by the social security and social protection systems in the labor and capital markets and ultimately on long-term output performance in the United States. Social spending, including pensions as well as unfunded benefits averaged $10.4 \%$ of GDP over the last four decades in the US and were financed by payroll taxes (about $60 \%)$ and the remaining by general tax revenues. [See EU (2013)]. The generosity of the social programs in the US is notably lower than in most of the rich democracies with which it is usually compared and there is a growing movement in the media and in the political arena in the direction of expanding benefits.

$\left(^{*}\right)$ We would like to thank Rui Pereira for very helpful comments and suggestions. 
Our starting point is the concern that a social spending system with pensions financed mostly on a pay-as-you-go basis with defined benefits and with a large unfunded component financed through general revenues, is likely to have a negative impact on long-term economic performance. In terms of the pension part of the system, this financing mechanism implies that the relationship between contributions and benefits is fuzzy and, therefore, payroll contributions are perceived to a certain extent as taxes on labor income. To the extent that the burden of these taxes is borne by producers they may increase the costs of labor and adversely affect the unemployment rate and, to the extent that these taxes are borne by workers, they may reduce disposable income and overall private savings and ultimately capital formation [see Brauninger (2005), Feldstein (1996), and Gramlich (1996)]. The general point is that the further away the pension systems are from a more actuarially-based system, the more distortionary they will tend to be [see Disney (2006)]. As to the unfunded component of the social protection system, its distortionary effects depend on the mix of tax revenues used to finance it, which includes part of the payroll tax.

Our empirical results are based on estimating a vector autoregressive model, relating GDP, unemployment rates, saving rates, and social spending. Our methodology allows for the consideration of both the contemporaneous correlations and the dynamic feedbacks among the different variables. This means that social spending is an endogenous variable and that feedbacks from the economy to social spending decisions are fully accounted for. In addition, both contemporaneous correlations and dynamic feedbacks are critical in the identification of innovations in social spending and in the measurement of their effects.

Although our focus is different, our approach brings us close to the literature on fiscal multipliers [see, for example, Ramey (2011)]. It is in fact very much in the spirit of the approach pioneered by Blanchard and Perotti (2002), which is based on VAR estimates and the Choleski decomposition for the variance covariance matrix of the residuals of the policy function to identify government spending shocks.

\section{Data and Preliminary Analysis}

\subsection{Data sources and description}

We consider GDP, the unemployment rate, the private gross saving rate (as a \% of the GDP), and social spending (also as a \% of the GDP). Data are from the Statistical Annex of the European Economy, EU (2013). The sample period starts in 1970. We 
exclude information after 2007 to avoid contaminating our results with the effects of the international economic and financial crisis that followed.

Social spending covers the full spectrum of activities of the social security and protection systems. It comprises public retirement pensions for employees, their dependents and their survivors, disability pensions, as well as unfunded social benefits for employees and social assistance programs. Our choice of social spending as the relevant variable is meant to reflect the true dimension of the social protection system and therefore the true dimension of its burden on the economy. The possible existence of a known structural break in 1983, the year of the last major reform of the social security system, is fully incorporated throughout our analysis.

\subsection{Unit roots, cointegration analysis and VAR specification}

We start by using the ADF test to determine the order of integration of the variables. The optimal lag structure is chosen using the BIC, and deterministic components as well a structural break are included when statistically significant. For the variables in log-levels, all $t$-statistics are lower in absolute value than the $5 \%$ critical values. In turn, in growth rates, all $t$-statistics are greater in absolute value than the $5 \%$ critical values. Accordingly, all variables are stationary in growth rates.

We next test for cointegration using the Engle-Granger procedure, which has proven less vulnerable than the Johansen procedure to the small sample bias toward finding co-integration when it does not exist [see, for example, Gonzalo and Lee (1998)]. We apply the ADF $t$-test to the residuals from the regressions of each of the four variables on the remaining variables. Again, the optimal specification is chosen using the BIC. In all cases, the $t$-statistics are lower, in absolute value, than the $5 \%$ critical values. Accordingly, we cannot reject the null hypothesis of no cointegration.

We then estimate the VAR model in growth rates. We find that the BIC leads to the selection of a first order specification with a constant and a trend and that the structural break in 1983 is not significant.

\subsection{Identification of the effects of shocks in social spending}

We use the accumulated impulse-response functions associated with the estimated VAR model to obtain the effects of innovations in social spending. The key methodological issue is identifying shocks to social spending that are not contemporaneously correlated with innovations in the remaining variables. In dealing 
with this issue, we draw from the standard approach in the monetary policy literature [see, for example, Christiano, et al. (1996), and Rudebusch (1998)] and consider a policy function, which relates the rate of growth of social spending to the relevant information set. The residuals from this policy function reflect the unexpected component of the change in social spending.

We assume that the information set includes past but not current observations of the other variables. This is equivalent in the context of the Choleski decomposition to assuming that, contemporaneously, shocks in social spending affect economic performance but are not affected by it. This seems to be a reasonable assumption since social spending reforms have been driven by long-term political considerations as opposed to very short-term macroeconomic conditions. The policy function estimates are reported in Table 1 and suggest that the evolution of social spending is exogenous relative to the other variables. This result is in line with Romer and Romer (2013) where social security spending is shown not to respond to short-term macroeconomic developments. This further confirms the appropriateness of our identifying assumption.

\section{Social Spending and Economic Performance}

\subsection{Measuring the effects of social spending}

We consider a one-time innovation in the growth rate of social spending. The accumulated impulse-response functions and the corresponding error bands are presented in Figure 1. The error bands surrounding the point estimates convey uncertainty around estimation and are computed via bootstrapping. To strengthen our results we consider $80 \%$ intervals although bands that correspond to a $68 \%$ posterior probability or one standard error are standard in the literature.

We estimate the long-term accumulated elasticities with respect to social spending as the long-term accumulated changes in the different variables, for a one percent long-term accumulated change in social spending. In turn, the long-term accumulated marginal products are the percentage point change in each variable for a one percentage point change in social spending as a percentage of the GDP. They are obtained by multiplying the elasticities by the average ratio for the last ten years of the sample of the corresponding variable to social spending. This allows us to interpret the marginal products as the effects under the most recent economic conditions while at the same time avoiding business cycle effects. Estimation results are presented in Table 2. 


\subsection{On the effects of social spending}

We find that social spending has negative effects on the labor markets as the unemployment rate reacts to social spending with an elasticity of 0.59 . This implies that in the long term the unemployment rate increases by 0.25 percentage points when social spending increases by one percentage point of the GDP. This result is in line with the negative effects on unemployment often found in the literature. Mortensen and Pissarides (1999) and Marimon and Zlibotti (1999), for example, explain the higher unemployment rates observed in Europe relatively to the United States based on the idea that the unemployed in a country with extensive social protection spend more time searching for a job which fully matches their skills.

We also find that social spending has a positive effect on savings with an elasticity of 0.74 . This implies that in the long term the gross savings rate increases by 0.90 percentage points when social spending increases by one percentage point of the GDP. This result falls within the broad spectrum of evidence in the literature. Lee and Chang (2006) and Obben and Waayer (2009), for example, find positive effects for a panel of OECD countries and New Zealand while Disney (2006) and Samwick (2000), for example, find evidence for negative effects for several OECD countries.

Finally, we find that social spending has a negative effect on GDP with a longterm elasticity of -0.33 . This implies that in the long term \$1 dollar increase in social spending leads to a \$2.8 decrease in GDP. This negative effect mirrors the negative effect on unemployment and occurs despite a positive effect on savings. This is consistent with the evidence in Conesa and Garriga (2008) that social security reforms are much more effective in eliminating distortions in the labor market than in enhancing savings. Overall, the negative effect of social spending on GDP is also consistent with the international literature. Afonso and Alegre (2011) and Ehrlich and Kim (2007), for example, estimate negative impact of social protection expenditures on output in a panel of EU countries, and of mostly OECD countries, respectively. Benos (2009) using a panel of EU countries and Romer and Romer (2013) for the US, however, find no significant detrimental effects.

\section{Concluding Remarks}

We show that social spending has significant distortionary effects in the labor markets as measured by its long term effects on the unemployment rate, which translate 
into a detrimental effect on long-term output, this despite a positive, albeit small, effect on the gross savings rate.

There are important policy implications of this result in particular in light of the ongoing demands for expanding the generosity of the social protection systems in the US. If one considers the systems as they are now, any further expansion in their generosity would have detrimental effects on long-term unemployment and output. These detrimental effects, however, are neither an indictment of social spending or evidence against expansion of benefits. In fact, although we measure the efficiency effects of the system we do not measure the economic and welfare benefits induced by its insurance or redistributive functions. What our results highlight is the need to carefully reconsider the current financing mechanisms, the need to align benefits and contributions in the pension component of social spending and to find a tax mix that is less distortionary for the unfunded benefits.

\section{References}

Afonso, A. and J. Alegre (2011). "Economic Growth and Budgetary Components: A Panel Assessment for the EU,” Empirical Economics 41 (3), 703-23.

Benos, N. (2009). "Fiscal Policy and Economic Growth: Empirical Evidence from EU Countries," Munich Personal RePEc Archive Paper 19174.

Blanchard, O. and R. Perotti (2002). “An Empirical Characterization of the Dynamic Effects of Changes in Government Spending and Taxes on Output,” Quarterly Journal of Economics 117, 1329-68.

Brauninger, M. (2005). "Social Security, Unemployment, and Growth," International Tax and Public Finance 12, 423-34.

Christiano, L., M. Eichenbaum, and C. Evans (1996). “The Effects of Monetary Policy Shocks: Evidence from the Flow of Funds,” Review of Economics and Statistics 78(1), 16-34.

Conesa, J. and C. Garriga (2008). “Optimal Fiscal Policy in the Design of Social Security Reforms,” International Economic Review, 49 (1), 291-318.

Disney, R. (2006). "Household Saving Rates and the Design of Social Security Programs: Evidence from a Country Panel,” National Institute Economic Review 198, 61-74. 
Ehrlich, I. and J. Kim (2007). "Social Security, Demographic Trends, and Economic Growth: Theory and Evidence from the International Experience," Review of Economic Dynamics 10 (1), 55-77.

European Union (2013). Statistical Annex of the European Economy - Autumn 2013. Directorate General of Economic and Financial Affairs.

Feldstein, M. (1996). "Social Security and Savings: A New Time Series Evidence,” National Tax Journal 49, 151-64.

Gonzalo, J. and T. Lee (1998). "Pitfalls in Testing for Long-Run Relationships,” Journal of Econometrics 86, 129-154.

Gramlich, E. (1996). "How Does Social Security Affect the Economy?” in Social Security in the $21^{\text {st }}$ Century, E. Kingson and J. Schultz (Eds). Oxford University Press.

Lee, C and C. Chang (2006). “Social Security Expenditure and GDP in OECD Countries: A Cointegrated Panel Analysis,” International Economic Journal 20(3), pp. 303-320.

Marimon, R. and F. Zilibotti, (1999). "Unemployment vs. Mismatch of Talents: Reconsidering Unemployment Benefits," Economic Journal 109, 266-91.

Mortensen, D. and C. Pissarides (1999). "Job reallocation, employment fluctuations and unemployment," in Handbook of Macroeconomics, J. Taylor and M. Woodford (Eds.). Elsevier.

Obben J. and M. Waayer (2009). "The Dynamic Relationship between the State Pension Scheme and Household Saving in New Zealand,” Discussion Paper 09.09 Department of Economics and Finance, Massey University.

Ramey, V. (2011). “Can Government Purchases Stimulate the Economy?” Journal of Economic Literature 49 (3), 673-85.

Romer C. and D. Romer (2013). Transfer Payments and the Macroeconomy: The Effects of Social Security Benefit Changes, 1952-1991. Mimeo.

Rudebusch, G. (1998). “Do Measures of Monetary Policy in a VAR Make Sense?” International Economic Review 39, 907-31.

Samwick, A. (2000). “Is Pension Reform Conducive To Higher Saving?” Review of Economics and Statistics 82 (2), 264-72. 
Table 1: Policy Functions for social spending

\begin{tabular}{|c|l|l|l|l|l|c|}
\hline Constant & Trend & Dummy & GDP(-1) & Saving(-1) & Unemp(-1) & $\begin{array}{c}\text { Social } \\
\text { spending } \\
\mathbf{( - 1 )}\end{array}$ \\
\hline 0.0195 & $\begin{array}{c}0.0011 \\
(0.76)\end{array}$ & $\begin{array}{l}-0.0454 \\
(0.78)\end{array}$ & $\begin{array}{c}0.0605 \\
(-1.26)\end{array}$ & $\begin{array}{c}-0.0821 \\
(-0.44)\end{array}$ & $\begin{array}{c}0.0302 \\
(0.24)\end{array}$ & $\begin{array}{c}(1.76) \\
\end{array}$ \\
\hline
\end{tabular}

Table 2: Long-term effects of social spending

\begin{tabular}{|c|c|c|c|c|c|}
\hline \multicolumn{2}{|c|}{ Unemployment rate } & \multicolumn{2}{|c|}{ Saving rate } & \multicolumn{2}{c|}{ GDP } \\
\hline Elasticity & $\begin{array}{c}\text { Marginal } \\
\text { products }\end{array}$ & Elasticity & $\begin{array}{c}\text { Marginal } \\
\text { products }\end{array}$ & Elasticity & $\begin{array}{l}\text { Marginal } \\
\text { products }\end{array}$ \\
\hline 0.5867 & 0.2473 & 0.7358 & 0.8953 & -0.3283 & -2.8312 \\
\hline
\end{tabular}

Notes: All effects are statistically different from zero in the sense that the $80 \%$ standard deviation bands do not include zero for unemployment and savings. The same is true for GDP with the standard one standard deviation bands. 
Figure 1: Accumulated impulse-response functions

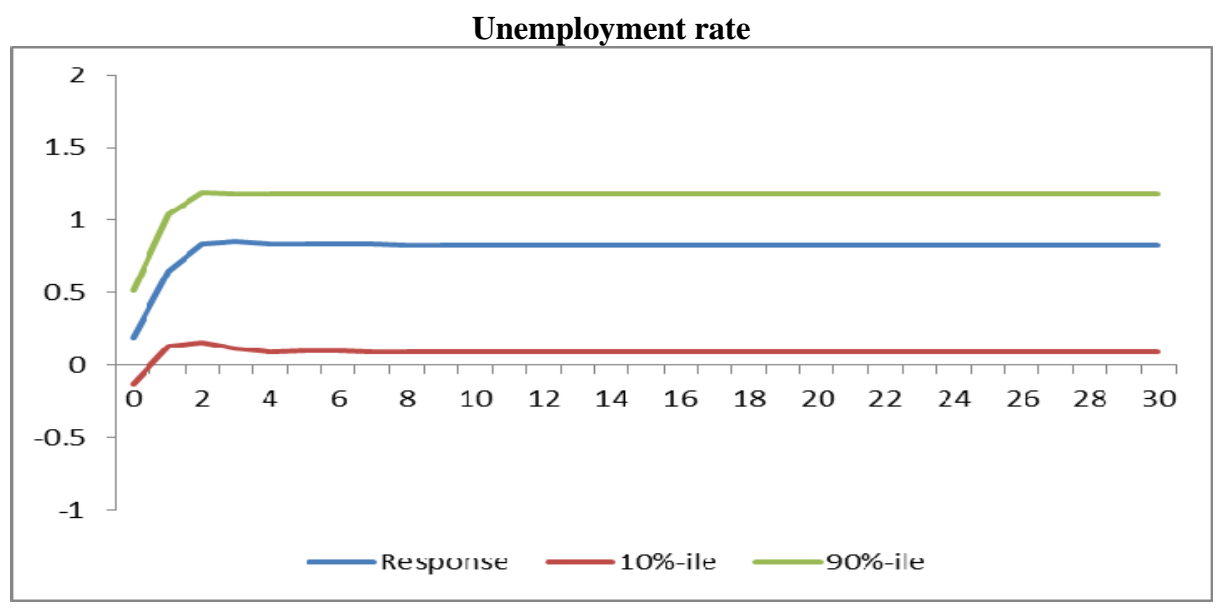

Saving rate

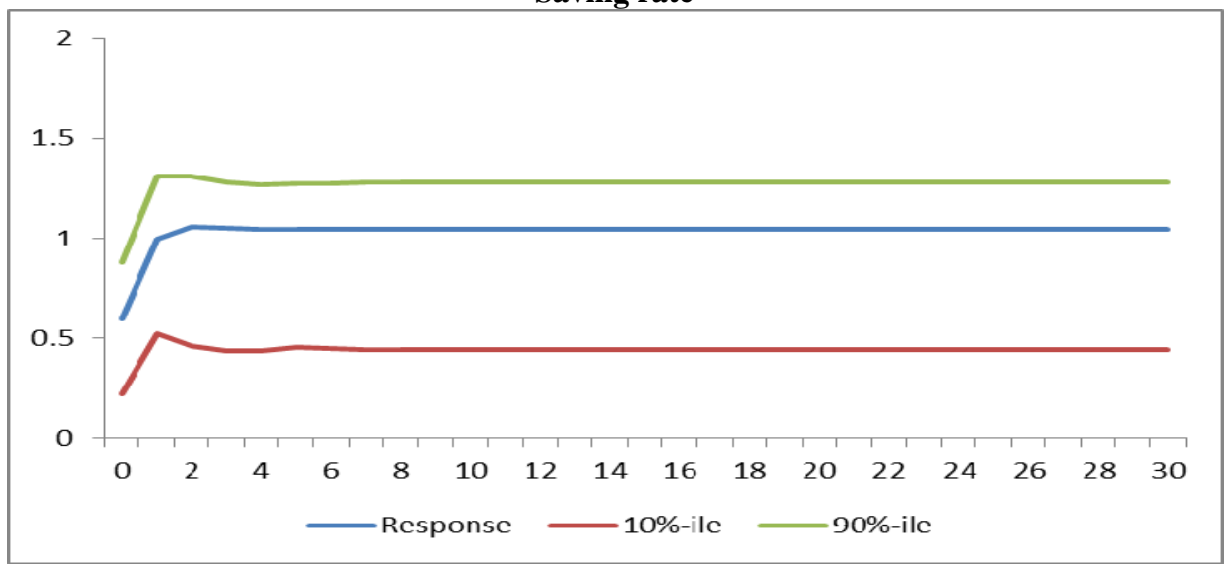

GDP

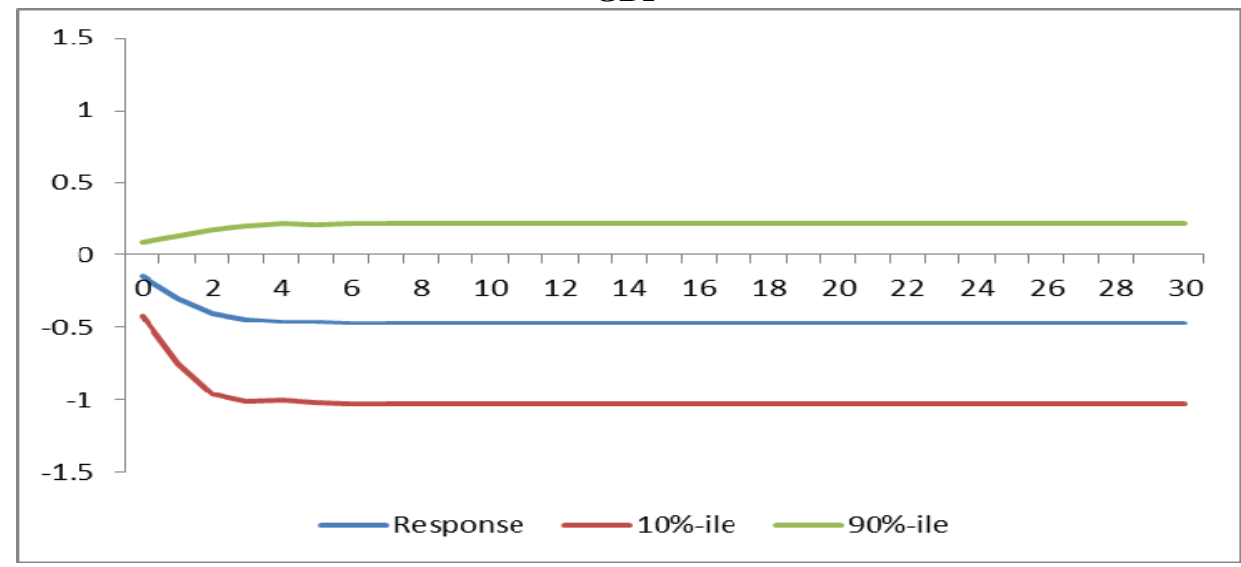

